\title{
КРИЗИС
}

\section{ОАНОПОАЯРНОГО МИРА}

\author{
Спиридонов В.В.
}

\author{
К ВОПРОСУ О СОЗААНИИ \\ БАНКА РАЗВИТИЯ БРИКС: \\ ПЕРСПЕКТИВЫ, ПОТЕНЦИАА, \\ ПРЕИМУЩЕСТВА
}

\begin{abstract}
Аннотация. Статья посвящена анализу изменений в международных экономических отношениях, которые произошли в результате создания Банка развития БРИКС, решение о создании которого было принято на саммите БРИКС в 2014 году. Официальными иелями создания этой международной организачии является развитие финансово- экономического сотрудничества между государствами, стабилизачия последствий экономических шоков, сглаживание диспропориий развития мирового хозяйства, преодоление финансовых кризисов, финансовая помощь и оздоровяение экономик развивающихся стран. В этом плане Банк развития БРИКС должен сыграть уникальную роль в формировании новой финансовой системы, в которой доляар уже не будет для всего мира единственной резервной валютой. Предметом настоящего исследования является роль Банка развития БРИКС в стабилизачии мировой финансовой системы. Методология настолщего исследования включает в себя системный, структурно- функииональный и сравнительный подходы, методы финансово-экономического анализа, синтеза, моделирования, наблюдения, экспертных оценок. Обострение внутриполитического кризиса на Украине привело к тому, что в мире начамось серьёзное экономическое давление на Россию. Объективных экономических причин этому нет: Россия выступает как надёжный внешнеэкономический партнёр. Подтверждением этому является создание в 2014 году международного Банка развития БРИКС. Настоящая статья связана анализом возможностей стран-участнии БРИКС на международной экономической, финансовой и политической арене. Проведены исторические параллели взаимодействия России смеждународными финансовыми организачиями.

Ключевые слова: Конфликтология, внешняя политика, Россия, БРИКС, дипломатия, экономическая политика России, Банк развития БРИКС, международные финансовые организации, кризис на Украине, финансы.
\end{abstract}


«ГАввное, чтобы костюмчик сидел!» А. Аербенёв

O Аной из веАущих мировых финансовых организаций явмяется МежАународный валютный фонА (МВФ). Примечательна история взаимоАействия этой финансовой организации со странами, обратившимися в своё время за помощью к ней. Рассмотрим исторический аспект взаимодействия России и МВФ. Итак, в начаме 90 - х г.г. прошлого века вслеАствие разрушительных политических и экономических процессов на постсоветском пространстве Россия обратилась к МВФ за финансовой помощью. Аальнейшие взаимоотношения России с указанной финансовой организацией скмаАывались следующим образом. Правительство России официа ьно обратилось в МВФ за финансо-

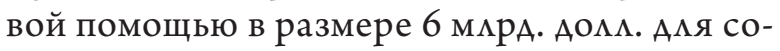
зАания так называемого фонда стабимизации. Первое соглашение о помощи бымо подписано Аиректором-распорядителем МВФ Камдессю и российской стороной в июле 1992 г., а уже в августе был предоставлен первый транш в размере 1 мкрА. Аолм., который испо ьзовался Аля пополнения валютных резервов, осуществления платежей по внешнему Аолгу, интервенций на валютном рынке. ПослеАующих траншей резервного кредита Россия, согласно подписанному соглашению, не получима. МВФ отказался также выделить среАства, преАназначенные Аля фонда стабимизации рубця, составляющие 6 млрА. Аолм. ПреАставители МВФ объяснили отказ уклонением российского правительства от выполнения согласованной стабимизационной программы. Кроме того, объём ВВП уменьшился почти на $15 \%$, Аефицит федерального бюАжета составим 22,4\% согласно методолгии МВФ, инфмяция переванима за 20\% в месяц.

Несмотря на это, в 1993 г. МВФ снова преАложил России креАит - второй по счёту - в размере 3 млрА. Аолм. в рамках направления «Помощи системным преобразованиям» (System Transformation FacilitySTF). Этот креАит сопровожАался менее жёсткими условиями и основным требованием его было то, чтобы российская сторона не вводила торговых ограничений. ОАнако в этом же 1993 г. МВФ приостановим передачу Аенег РФ вследствие того, что Правительство РФ не обеспечимо слерживание инфмяции и не провело сокращения бюАжетных расходов. В 1994 г. Россия покучика второй транш креАита 1,5 мирА. Аоли. на ПоААержку системных преобразований в стране. Вместе с тем, Правительство РФ взяло жёсткий курс на подавление инфмяции в качестве главной макроэкономической цели, что вызвало ко-

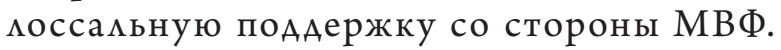
В результате, на слеАующий 1995 г. России был предоставлен резервный стабилизационный кредит в размере в 6,8 мирА. Аол .

ОАнако в 1998 г. экономическая ситуация в России резко ухудшилась. Это было связано с падением цен на энергоносители на мировых рынках. Аля России это сказалось следующим образом: 1) платёжный баманс по счету текущих операций превратился в первом покугоАии из активного в пассивный; 2) Аефи-

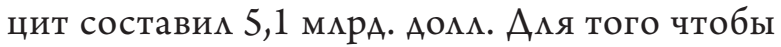
сбалансировать госуАарственный бюАжет и преАотвратить резкую девацьвацию рубля, Правительством РФ была разработана антикризисная программа. Имея план спасения экономики, российская сторона обратилось к МВФ за финансовой помощью. В результате была достигнута договоренность с МВФ о предоставлении креАита четырьмя траншами, первый из которых был выделен. ОАнако было Уже слишком позАно: 17 августа 1998 г. в Росии бым объявлен Аефолт по облигациям краткосрочного займа. После указанных критических Аля нашей страны событий финансовой помощи от МВФ Россия не получала. В 2005 г. Правительство РФ Аосрочно погасимо Аолг пере А МВ в размере 3,3 мирА. Аом . А вот зАесь автору настоящей работы хотелось бы обратить внимание читателя на то, что с момента Аефолта в России Ао полного погашения креАита МВФ прош $о$ 7 мет. Это ми не экономиче ское чудо? А совершить это чудо УАа ось во многом благоАаря спокойным, уверенным, прагматичным, профессиональным Аействиям Е.М. Примакова.

Итак, взаимоотношения России с запаАными межАународными финансовыми организациями скмадывались весьма непросто, иногАа - Араматично. Тому есть ряА причин: 
- в начале 90-х г.г. прошлого века Россия не могма обойтись без значительных внешних финансовых заимствований. Потребность в них была вызвана помнейшей экономической Аестабилизацией, связанной с распадом СССР, колоссальными труАностями перехоАного периоАа к новой моАеАи экономики. Без креАитов, ссуА, займов от межАународных организаций, эмиссии Аолговых ценных бумаг А^я нерезидентов, зарубежной гуманитарной, технической помощи пережить прехоАные времена бымо очень непросто.

- после разрушительных процессов на постсоветстком просранстве не были созАаны преАпосылки, позволившие отказаться от внешней финансовой помощи. КреАиты шли на затыкание бюАжетных дыр, финансирование импорта преАметов потребления, обслуживание государственного Аолга, который всё возрастац и возрастац. Таким образом, финансовая помощь попросту проеАалась. Поэтому и взаимодействия со стороны МВФ и России были осторожными.

В последние же годы, по мере восстановмения позиций России на мировой экономической и политической арене, начали яркими вспышками стали проявляться противоречия межАу Россией и межАународными запаАными финансовыми и рейтинговыми организациями.

Связано это с тем, что Россия как могущественная экономическая Аержава перестала мириться со своего рода подчиненным, неравным положением по отношению к запаАным странам.

Украинский кризис, начавшийся в 2013 г., ещё более обострил противоречия России с западными странами. Против России начаАась откровенная травця, запугивания экономическими санкциями. Началось- с искмючения России из Клуба восьми экономически развитых государств- G-8. По-видимому, ожиАались просьбы российской стороныпринять ее. Затем последовала информационная истерика с текущими рейтингами и прогнозами экономического развития России. ОАнако, как весьма АальновиАно отметил в своих работах А.В. Манойло, Россия является участником Аругого - не менее значимого в мировой экономике кмуба - БРИКС. Отмечу, что на созАание своеобразного треугольника сотруАничества с ИнАией и Китаем и Аиверсификации российской внешней политики от чрезмерной ориентации на страны Запада указал в 90-х г.г. прошлого века Е.М. Примаков. По целому ряду причин преАложенный треугольник в те гоАы не мог быть полноценно реализован, но на сегодняшний день все три страны смогли разрешить или же отложить в сторону существующие разногласия и активно сотрудничают уже в многомерном формате- БРИКС.

Самая послеАняя встреча пяти мидеров стран БРИКС состоямась переА началом на саммите «Группы Авадцати» в Аос-Кабоce (Мексика) в июне 2012 гоАа, что позволило пяти странам договориться по важнейшим межАународным финансово-экономическим и политическим вопросам. Эта сессия состояла из обсужАений проблем кризиса Еврозоны, реформы МВФ, Аальнейших перспектив «Большой АваАцатки». Российской стороной был сАелан упор на важность разработки АОлгосрочной стратегии развития и созАания Аелового совета БРИКС.

Кроме того, украинский кризис не поскужил причиной охлажения отношений межАу российской стороной и остальными странами блока. Это свидетельствует о том, что контакты межАу странами БРИКС не осложняются надуманными политическими причинами.

Это подтверАикось в разгар фееричного Чемпионата мира по футболу, 15 июля 2014 года, в день открытия VI саммита БРИКС в бразильском городе Форталеза. Именно в этот Аень участники БРИКС объявики о созАании собственного Банка развития.

Аидеры стран БРИКС Аоговорились также об объёме и структуре капитала Банка.

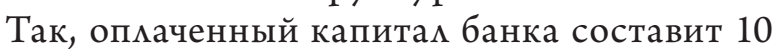
мирА. Аом ., буАет распреАелён пропорционально межАу участниками договора. Объём разрешенного капитала банка составит в ближайшем буАущем 100 млрА. Аолм., а распреАе-

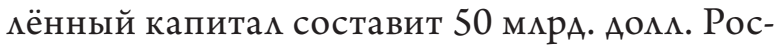
сия намерена внести в капитал банка 2 ммрА. Аолм. в течение семи мет. Новая структура ещё не имеет утвержАённого устава, но уже сейчас преАполагается, что банк будет креАитовать проекты в развивающихся странах. Важно, 
Таблица 1. Динамика изменения объёмов ВВП БРИКС за период с 2008-2013 г.2.

\begin{tabular}{|l|l|l|l|l|l|l|} 
Страна & $\begin{array}{l}\text { ВВП 2008 г., } \\
\text { млрд. долл }\end{array}$ & $\begin{array}{l}\text { ВВП 2009 г., } \\
\text { млрд. долл }\end{array}$ & $\begin{array}{l}\text { ВВП 2010 г., } \\
\text { млрд. долл }\end{array}$ & $\begin{array}{l}\text { ВВП 2011 г., } \\
\text { млрд. долл }\end{array}$ & $\begin{array}{l}\text { ВВП 2012 г., } \\
\text { млрд. долл }\end{array}$ & $\begin{array}{l}\text { ВВП 2013 г., } \\
\text { млрд. долл }\end{array}$ \\
\hline Бразилия & 1573 & 1652 & 2090 & 2400 & 2222 & 2190 \\
\hline Россия & 1661 & 1222 & 1480 & 1885 & 2053 & 2200 \\
\hline Индия & 1238 & 1224 & 1365 & 1710 & 1880 & 1858 \\
\hline Китай & 4520 & 4990 & 5878 & 6989 & 8250 & 8939 \\
\hline ЮАР & 286 & 273 & 284 & 365 & 403 & 382 \\
\hline
\end{tabular}

что финансироваться буаут только внешние, а не внутренние проекты. Суть подобного условия состоит в том, что Аля внутренних проектов существуют национамьные фонАы. Например, в России это Резервный фонА. При выходе на зарубежные рынки участники Банка развития могут получить выгодные преференции. Банк развития БРИКС буАет выдавать своим партнёрам кредиты в национамьных валютах. Соглашение об этом бымо поАписано на саммите стран БРИКС, оАнако конкретных сроков сАелок без участия Аолмара пока не обозначено. Указанное соглашение усилит финансовое сотруаничество, а также поААержит компании, стремящиеся выйти на рынки БРИКС. Кроме того, неоспоримым Аостоинством создания подобного финансового института является и то, что страны-участники БРИКС, во-первых, смогут ограничить вмешательство иностранного капитала в свои внутренние дела, а во-вторых, выступлт своего рода гарантом невмешательства во внутренние дела других стран, предоставив им самим возможность решения собственных проблем, не отказывая при этом в помощи. Российская сторона решитемьно и активно выступима за создание Банка развития БРИКС, поскомьку новая банковская структура станет серьезной амьтернативой Всемирному банку, Международному валютному фонду. Таким образом, появился реальный шанс уменьшить финансово-политическое вмияние Евросоюза и США на мировые экономические процессы, в частности, минимизировать негативное вмияние на Россию и её экономических партнёров.

Что касается негативного влияния на Россию, то помитический кризис на Украине показал, что мюбые самостоятельные действия со стороны России, идущие вразрез с политикой так называемого «мирового гегемона», даже не относящиеся $к$ экономике чреваты экономическим давлением.

В этой связи весьма актуамьно, по мнению автора, будет напомнить «гегемону» русскую пословицу: «В огороде бузина, а в Киеве АяАька». Получается, что преодолеть политический кризис на территории независимого иностранного государства можно только путём экономического Аавления всего прогрессивного мирового сообщества на Россию.

В итоге, в политический кризис на Украине оказались вовлечены и страны ЕС, грозящие торговыми санкциями в отношении России. Но Россия выступает импортёром товаров из Европы, поэтому санкции грозят наряду с Россией и европейским производителям колоссамьными потерями прибылей. У автора настоящей работы есть небезосноватемьные сомнения в том, что европейский бизнес-истеблишмент Аопустит собственные убытки. Кроме того, суть означенных торговых санкций, по мнению автора, непонятна и европейскому бизнесу.

Вместе с тем, некоторые российские банки уже ощутими на себе Аавмение со стороны иностранных госуАарств, на территории которых они осуществцяют свою Аеятемьность. Кому от этого будет хуже ими мучше-покажет время, но у автора настоящего исследования существует вполне обоснованная уверенность в том, что российские банки, на которые оказывается Аавмение, обязатемьно выстоят как финансовые институты. Это настолько крепкие кирпичи в стене мировой банковской системы, что выбивать их - значит разрушить эту стену. С Аругой стороны, хотемось бы напомнить, что финансового кризиса 20082009 г.г. не выдержами некоторые гиганты 
Таблица 2. Темпы роста экономики стран БРИКС за период с 2008-2013 г.г."

\begin{tabular}{|l|l|l|l|l|l|l|}
\hline Страна & $\mathbf{2 0 0 8}$ г.,\% & $\mathbf{2 0 0 9}$ г.,\% & $\mathbf{2 0 1 0}$ г.,\% & $\mathbf{2 0 1 1}$ г.,\% & $\mathbf{2 0 1 2}$ г.,\% & $\mathbf{2 0 1 3}$ г.,\% \\
\hline Бразилия & 5,2 & $-0,6$ & 7,5 & 2,7 & 0,9 & 2,5 \\
\hline Россия & 5,2 & $-7,8$ & 4,0 & 4,3 & 3,5 & 1,3 \\
\hline Индия & 6,2 & 6,8 & 10,1 & 6,3 & 3,2 & 3,8 \\
\hline Китай & 9,6 & 9,2 & 10,4 & 9,3 & 7,7 & 7,6 \\
\hline ЮАР & 3,6 & $-1,7$ & 2,9 & 3,5 & 2,5 & 2,0 \\
\hline
\end{tabular}

“МежАународный валютный фонА: [Official site]. URL: www.imf.org (6.07.2014)

банковского бизнеса, созданные и действующие на территории собственного государства. Причём это госуАарство- мировой миАер по такому экономическому показателю, как ВВП, не смогмо спасти эти банки, просуществовавшие, кстати, не одну сотню мет и выдержавшие не оАно экономическое потрясение.

Именно поэтому сейчас как глоток свежего воздуха воспринимается сообщение о создании нового финансового института, который будет заниматься своим прямым делом-экономической и финансовой деятельностью.

Но какова же ресурсная база Аля создания этого Банка? Сможет ми он выстоять переА возможными экономическими и финансовыми вызовами и шоками? Аля ответа на этот вопроспроанахизируем важнейшие экономические показате и стран-участников БРИКСБразилии, России, ИнАии, Китая, ЮАР.

В таблице 1 привеАена Аинамика объёмов ВВП стран БРИКС за периоА с 2008-2013 г.г. ${ }^{1}$

Какследует из преАставленной таблицы 1 ,

a) ВВП Бразимии в течение указанного периода изменялся следующим образом: в 2008 г. ВВП составим 1573 мирА. Аом ., а в 2013 г. уже 2190 млрА. Аолм. ОАнако с 2011 г. ВВП Бразимии снижался.

б) ВВП России в течение указанного периода изменялся несколько иначе. Сначалалемонстрировал падение в 2009 г. Ао 1222 млрА. АОА . по сравнению с 2008 г., а затем уверенный рост Ао 2200 м АрА. АОА . в 2013 г.

в) ВВП ИнАии в течение указанного периода изменялся следующим образом: показывал тенденцию к незначительному росту: от 1238 мирА. АОАл. в 2008 г. Ао 1858 мирА.

\footnotetext{
${ }^{1}$ Международный валютный фонА: [Official site]. URL: www.imf.org (6.07.2014)
}

АОАл. в 2013 г. В 2009 г. ВВП ИнАИи снизился по сравнению с 2008 г., а затем стабимьно увеничивался.

г) ВВП Китая в течение указанного периоАа изменялся слеАующим образом: стабильно увекичиваясь, в 2008 г. ВВП Китая составил 4520 млрА. Аолм., а в 2013 г.- уже 8939 м мрА. Аолм. Таким образом, увекичение ВВП Китая, не испытывая «провалов», увеличился в 2 раза.

А) ВВП ЮАР в течение указанного периода изменялся следующим образом: в 2008 г. составив 286 мирА. Аолм., а в 2013 г.- уже 382

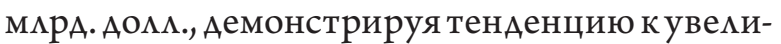
чению. ОАнако, в 2009 г. и в 2013 г. показатель ВВП ЮАР снижался по сравнению с преАыАущими отчётными периодами.

Более детальную информацию о развитии экономик стран БРИКС можно получить на основе анализа темпов их роста. В таблице 2 преАставлены данные по темпам изменения экономик стран-участниц БРИКС.

Как следует из преАставленной таблицы 2,

а) Темпы роста экономики Бразилии в течение указанного периода имели тенденцию к понижению: в 2008 г. Аанный показатель составим 5,2\%, в 2013 г. только 2,5\%, уменьшившись в 2 раза. Более того, в 2009 г. темп роста экономики Бразимии составим отрицательное значение $-0,6 \%$, что свидетельствует о спаде экономики.

б) Темпы роста экономики России в течение указанного периода показывали тенАенцию к понижению: в 2008 г. Аанный показатель составим 5,2\%, в 2013 г. только 1,3\%, уменьшившись в 4 раза. Более того, в 2009 г. темп роста экономики России составик отрицательное значение $-7,8 \%$, что свидетельствует о серьёзном спаде экономики. 
КОНФАИКТОАОГИЯ • 1(1) • 2014

Таблииа 3. Динамика государственного долга стран БРИКС за период с 2008-2013 г.г.

\begin{tabular}{|l|l|l|l|l|l|l|} 
& $\begin{array}{l}\text { Долг 2008 г., } \\
\text { млрд. долл }\end{array}$ & $\begin{array}{l}\text { Долг 2009 г., } \\
\text { млрд. долл }\end{array}$ & $\begin{array}{l}\text { Долг 2010 г., } \\
\text { млрд. долл }\end{array}$ & $\begin{array}{l}\text { Долг 2011 г., } \\
\text { млрд. долл }\end{array}$ & $\begin{array}{l}\text { Долг 2012 г., } \\
\text { млрд. долл }\end{array}$ & $\begin{array}{l}\text { Долг 2013 г., } \\
\text { млрд. долл }\end{array}$ \\
\hline Бразилия & 1038,1 & 1123,3 & 1337,6 & 1441,4 & 1584 & 1422,1 \\
\hline Россия & 116,2 & 134,4 & 162,8 & 194,3 & 226,2 & 143,71 \\
\hline Индия & 866,6 & 856,8 & 955,5 & 1001,2 & 1197 & 1316,0 \\
\hline Китай & 655,3 & 768,4 & 848,3 & 1469,5 & 1747,2 & 3300,0 \\
\hline ЮАР & 85,8 & 81,9 & 99,4 & 101,2 & 109,5 & 181,3 \\
\hline
\end{tabular}

* Аанные по России: Министерство финансов РФ: [Официальный сайт]. URL: www.minfin.ru (06.07.2014); Аанные по остальным странам БРИКС: МежАународный валютный фонА: [Official site]. URL: www.imf.org (6.07.2014)

Таблица 4. Динамика относительного государственного долга стран БРИКС за период с 2008-2013 г.2.

\begin{tabular}{|l|l|l|l|l|l|l|} 
& $\begin{array}{l}\text { Долг/ВВП } \\
\mathbf{2 0 0 8} \text { г.\% }\end{array}$ & $\begin{array}{l}\text { Долг/ВВП } \\
\mathbf{2 0 0 9} \text { г.\% }\end{array}$ & $\begin{array}{l}\text { Долг/ВВП } \\
\mathbf{2 0 1 0} \text { г., }\end{array}$ & $\begin{array}{l}\text { Долг/ВВП } \\
\mathbf{2 0 1 1} \text { г.,\% }\end{array}$ & $\begin{array}{l}\text { Долг/ВВП } \\
\mathbf{2 0 1 2} \text { г.,\% }\end{array}$ & $\begin{array}{l}\text { Долг/ВВП } \\
\mathbf{2 0 1 3} \text { г.,\% }\end{array}$ \\
\hline Бразилия & 63,6 & 68,1 & 54,7 & 54,2 & 58,8 & 59,2 \\
\hline Россия & 7,9 & 11,0 & 7,9 & 8,3 & 8,0 & 7,9 \\
\hline Индия & 73,1 & 69,4 & 50,6 & 50,5 & 51,7 & 51,0 \\
\hline Китай & 17,0 & 17,7 & 43,5 & 38,5 & 31,7 & 31,7 \\
\hline ЮАР & 26,8 & 30,9 & 33,4 & 38,6 & 42,3 & 45,4 \\
\hline
\end{tabular}

Млн. долл.

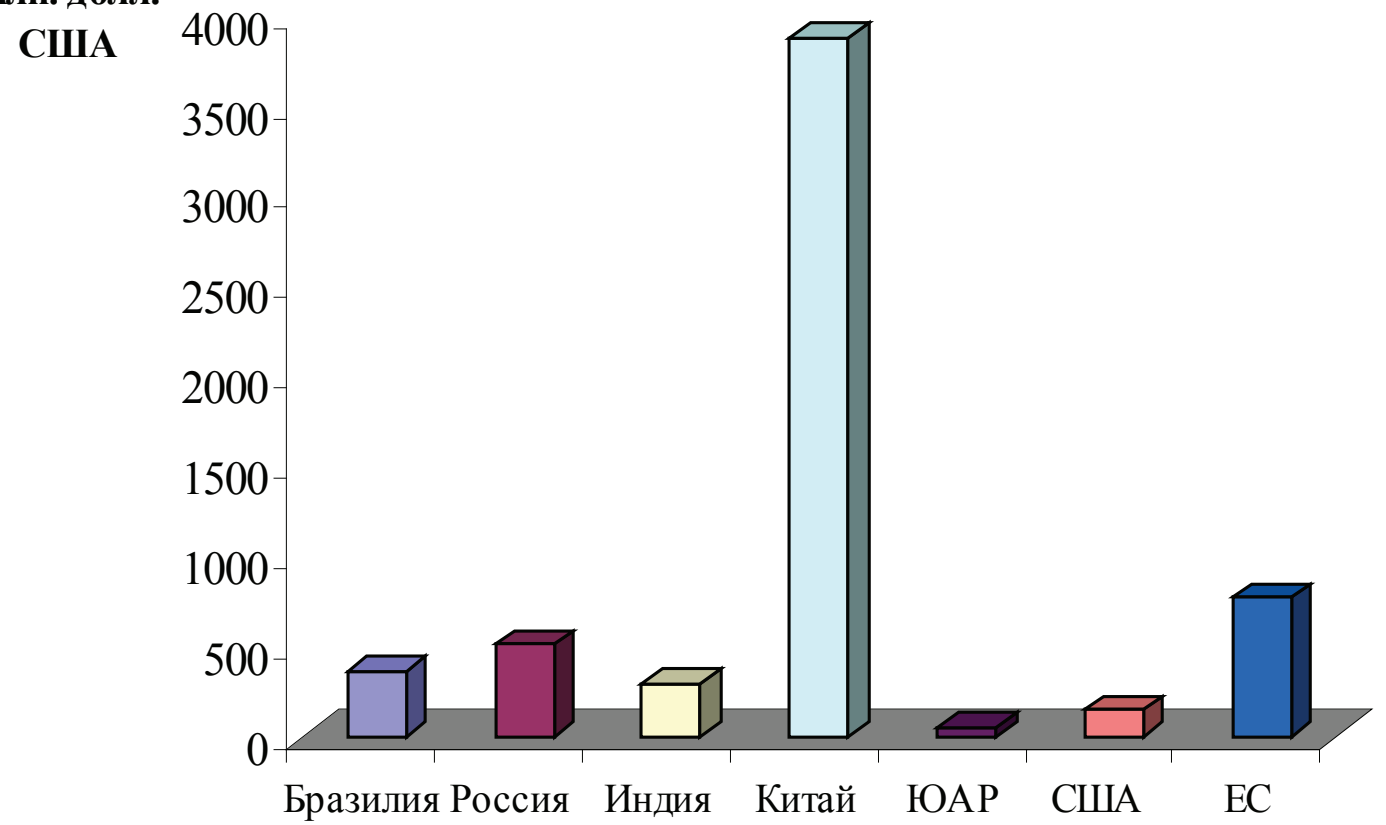

Рисунок 1. Величина междннародных резервов стран БРИКС, США, Европейского союза по состоянию на 2013 г. 
в) Темпы роста экономики ИнАии в течение указанного периода демонстрировали сначала тенденцию к повышению: в 2008 г. Аанный показатемь составим 6,2\%, в 2010 г. $10,1 \%$, однако уже со следующего года наметимась тенденция к уменьшению. В 2013 г. темп роста экономики ИнАии составим только $3,8 \%$.

г) Темпы роста экономики Китая в течение указанного периода имели тенденцию к понижению: в 2008 г. Аанный показатель составих 9,6\%, в 2013 г. 7,6\%, Никаких серьёзных комебаний темпов роста экономики Китая не было, однако было увеличение рассматриваемого показателя Ао 10,1\% в 2010 г.

А) Темпы роста экономики ЮАР в течение указанного периода показывали тенденцию к понижению: в 2008 г. Аанный показатель составил 3,6\%, в 2013 г. только 2,0\%, уменьшившись в почти 2 раза. Более того, в 2009 г. темп роста экономики ЮАР составиц отрица-

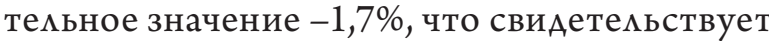
о серьёзном спаде экономики.

Важной характеристикой развития экономики мюбого государства является его государственный Аолг. В таблице 3 приведены Аанные по объёмам госАолга стран БРИКС.

Как следует из преАставменной таблицы 3 , общей чертой Аля всех рассматриваемых стран является тенденция к увеличению государственного долга. Это свидете ьствует о том, что Аля развития собственных экономик кажАая из стран группы БРИКС использует и Аолговые инструменты.

Вместе с тем, эффективностью использования Аанных инструментов служит величина отношения государственного Аолга к ВВП (относительного государственного Аолга) страны. Аанные по указанному показателю приведены в таблице 4.

Как следует из результатов, преАставленных в таблице 4,

a) соотношение государственного Аолга к ВВП в случае Бразикии в течение исслеАуемого периода имеет выраженную тенденцию к снижению: от 63,6\% в 2008 г. Ао 59,2\% в 2013 г. Это означает, что, проводя Аолговую политику, управляя Аолгом, финансовые власти Бразилии Аержат в постоянном соответствии доходы и обязательства страны. б) Особого внимания заскуживает отношение госАолга к ВВП в случае России. Указанная вемичина составляет 7,9\% в 2008 г. и точно такое же значение в 2013 г. Это свидете ььствует о том, что объём заимствований значительно меньше объёма ВВП, это, в свою очереАь, связано с жёсткой Аолговой политикой финансовых властей России и недопущением трансформации госАолга в инструмент политического вАияния на РФ на международной арене.

в) Соотношение государственного долга к ВВП в случае ИнАии в течение исследуемого периода имеет выраженную тенденцию к снижению: от 73,1\% в 2008 г. Ао 51,0\% в 2013 г. Это означает, что ПровоАя Аолговую Политику, УПрав яя Аолгом, финансовые власти ИнАии Аержат в постоянном соответствии АохоАы и обязательства страны.

г) Соотношение государственного долга к ВВП в случае Китая в течение исследуемого периода имеет выраженную тенденцию к повышению: от 17,0\% в 2008 г. до 31,7\% в 2013 г. Пик увеличения Аанного параметра прихоАится на 2010 г. и составляет 43,5\%.

А) Соотношение государственного долга к ВВП в случае ЮАР в течение исследуемого периода имеет выраженную тенденцию кувемичению: от $26,8 \%$ в 2008 г. Ао 45,4\% в 2013 г. Причём именно в 2013 г. указанный параметр принимает максимацьное значение Аля ЮАР.

ОАним из важнейших показателей экономической Аеятельности государства явмяется платёжный баманс. Все статьи этого государственного финансового документа явцяются важными, но в настоящей работе автором будет рассмотрена $\Lambda$ иш статья «МежАународные резервы». Объёмы межАународных резервов стран БРИКС, США, Европейского союза в 2013 г. приведены на рисунке $1 .^{1}$

Как следует из преАставленного рисунка 1 ,

1) Межаународные резервы Бразилии состав яют 357 м нн. Аол ., что соответствует 7 месту в мире по Аанному показателю;

\footnotetext{
${ }^{1}$ Аанные по России: Центральный Банк России: [Официальный сайт]. URL: www.cbr.ru (06.07.2014);

Аанные по остальным странам БРИКС: Международный валютный фонА: [Official site]. URL: www.imf.org (6.07.2014)
} 
2) Межаународные резервы России состав яяют 478 мин. Аолм., что соответствует 5 месту в мире по Аанному показателю;

3) Межаународные резервы Инаии со-

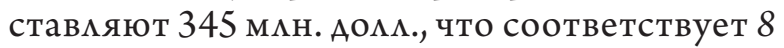
месту в мире по Аанному показателю;

4) Особого внимания заслуживают меЖаународные резервы Китая. Они составляют $3.820 \mathrm{м \Lambda н.} \mathrm{АО \Lambda \Lambda .,} \mathrm{что} \mathrm{соответствует} \mathrm{аб-}$ солютной мидирующей, первой позичии в мире по данному показателю;

5) МежАународные резервы ЮАР состав-

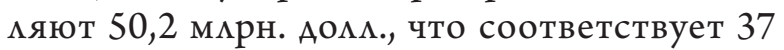
месту в мире по Аанному показателю.

6) Что касается совокупных межАународных резервов Европейского союза, то они составляют 771 млн. Аол . Это соответствует 3 месту в мире по Аанному показателю. США обладают межАународными резервами в количестве 146 млн. Аолм., что соответствует 18 месту в мире по Аанному показателю.

На основании проведённого анализа, слеАующие выводы:

Экономики стран БРИКС значительно отиичаются по своим объёмам и темпам роста: так, например, экономика Китая - мидера среАи указанных стран превосходит самую маменькую экономику - ЮАР - в 10 раз. Экономики Бразимии, России, ИнАии по объёмам сопоставимы, они меньше китайской экономики в 3 раза. Следует обратить внимание на колоссальный совокупный экономический потенциа союза БРИКС.

Общим Аля экономик стран БРИКС явмяется замеАление темпов роста. Серьёзные провалы в экономическом развитии некоторых стран указанного союза связаны с негативными послеАствиями мирового финансового кризиса.

Общим Аля всех стран БРИКС явмяется то, что им потребовацось совсем немного времени Аля восстановцения.

Важно отметить, что кажАая из стран группы БРИКС, взаимодействуя с остальными странами мира, тем не менее, реализовывала собственную политикуАля преодоления послеАствий мирового финансового и экономического кризиса с целью восстановцения своих экономик.
Важным политическим фактором взаимодействия стран БРИКС явцяется то, что несмотря на существенные отличия в объёмах экономик, темпах их изменения, реализации самостоятельной экономической политики, страны указанного союза проявцяют взаимный, обоюАный интерес к сотруаничеству, взаимодействию и взаимопомощи.

А теперь мы снова обратимся к МВФ Аля того, чтобы попытаться сопоставить исторический опыт Аанной межАународной финансовой организации с тем потенциалом, который несёт в себе Банк развития БРИКС.

Итак, МВФ является специализированным финансовым агентством ООН. Практическую Аеятельность фонд начал в мае 1946 г. ТогАа в него вошии 39 стран. СССР принял активное участие в Бреттон-ВуАской конференции, но статьи соглашения с МВФ не ратифицировал. На сегоАняшний день в состав МВФ входят 185 стран, почти все страныучастники ООН. Искмючение составляют Куба, Северная Корея, Андорра, Аихтенштейн, Монако, Науру.

Как упоминамось выше, миссией МВФ является регулирование валютно-креАитных отношений госуАарств-чменов и оказания им помощи при дефиците платежного баланса путем предоставления кратко- и среАнесрочных кредитов в иностранной валюте.

Высшим руковоАящим органом МВФ явмяется Совет управляющих, в котором кажАая страна-участник преАставлена управцяющим и его заместитемем. Все управмяющие собираются оАин раз в гоА на ежегодные Совещания МВФ и Всемирного банка. Политику МВФ контролирует МежАународный валютно-финансовый комитет - МВФК. Его 24 участника - министры финансов ими Аиректора Центральных банков стран и групп стран, преАставленных в Исполнительном совете.

Исполнительный совет МВФ отвечает за большинство решений. Он состоит из 24 исполнительных Аиректоров. Исполнительный совет выбирает на пятикетний срок Аиректора-распорядителя. По Аоговоренности межАу странами- учредитекями Фонда, АиректорраспоряАитель Аолжен быть преАставитель оАной из европейских стран, а Аиректором Всемирного банка гражАанин США. В на- 
стоящее время МВФ возглавляет К. АагарА (Франция). Кстати, большинство глав МВФ являкись гражАанами Франции. ФонА имеет преАставите ьства более чем в 80 странах мира, том числе в России.

МВФ получает АохоА от процентов и сборов по креАитам, использует его ААя покрытия издержек финансирования, оплаты аАминистративных расходов, накопления страховых остатков. Рекордные по объёму заимствования по Аинии МВФ- около 120 м РА. Аол . пришлись на 1997-1999 г.г. Крупнейшими получателями финансовой помощи в этот периоА стали страны, наиболее пострадавшие от потрясших мир финансовых кризисов: Южная Корея, Индонезия, Бразилия.

Условия чменства в МВФ и механизмы креАитования со сторны МВФ слеАующие: при вступлении в фонА кажАое госуАарство-участник выплачивает взнос по поАписке- квоту. Страны выплачивают $25 \%$ в счет своей квоты в виде резервныхактивов, так называемых специальных прав заимствования (SDR) ими основной валюты (Аолмар США, евро, японская йена, фунт стерлингов). В случае необходимости Аля целей креАитования МВФ может запросить у госуАарства-участника остальную часть, подмежащую выплате в национальной валюте. Размер квот пересматривается кажаые 5 мет. Общая сумма взносов госуаарствучастников образует уставный капитах МВФ, который используется А^я оказания помощи странам, испытывающим финансовые трудности. Расчёт квоты производится на основании данных об объёме ВВП страны, исходя из золотовалютных резервов государства и определяет сумму, которую оно может заимствовать у МВФ, а также его право голоса. Общая сумма квот в МВФ эквивацентна 217,4 мирА. SDR. Наибольшая квота у США 37,149 млрА. SDR ими $16,77 \%$ голосов, у России 5,945 млрА. SDR ими 2,69\% голосов. В бытность Аиректором-распорядителем МВФ А. Стросс-Канн, не поААержанный Россией при назначении, преАлагал снизить квоту России Ао 1,7\% и перевести её влияние на уровень стран Персидского замива, Таиланда, Аргентины. Таким образом, во-первых, заметна и очевидна антироссийская политика внутри МВФ. Во-вторых, в совокупности, СоеАиненные Штаты и Евросоюз обладают в настоящее время 50\% всей квоты при голосовании в МВФ. Таким образом, они могут провести кюбое решение вне зависимости от мнения Аругих стран, вместе взятых. Поэтому роль, в частности, Китая, России, Бразилии, Инаии в рамках МВФ сводится к номинацьному участию без принятия стратегически важных решений.

При предоставцении финансовой помощи ФонА требует от государства-Аолжника выполнения определенных условий, касающихся валютной системы, внешней торгов$\Lambda и$, баланса государственного бюАжета. ХоА выполнения обязательств контролируется путём периодического мониторинга экспертами МВФ состояния экономических показателей должника. Если буАут выявлены противоречия в использовании креАита соответствию миссии ФонАа, креАитование может быть ограниченно или полностью заблокировано в оАностороннем порядке. Таким образом, этот механизм позволяет МВФ оказывать как экономическое, так и политическое Аавление на государство-заёмщика.

Что касается экономического развития стран-участниц БРИКС, то они как в отАельности, так в совокупности Аемонстрируют некоторые макроэкономические показатеми: ВВП, межАународные резервы, которые значительно превосходят таковые Аля большинства стран мира. Указанные показатели формируют позицию в МВФ. ОАнако, несмотря на то, что согласно Устава МВФ, позиция стран-участниц БРИКС Аолжна быть симьнее, но пересмотра позиций, и, как слеАствие, усимения права принятия решений в рамках МВФ, не происходит. Более того, имели место попытки искусственно занизить, в частности, значение России в МВФ. Также хотелось бы прокомментировать эпимог настоящего исследования. Отношения многих стран, в том чисме и России, с западными финансовыми организациями напоминают какой-то «моАный приговор». Россию пытаются нарядить в костюм, который ей совсем не мицу: ни фасоном, ни размером, ни цветом, ни качеством материала. В России есть свои портные, которые понимают, что нашему государству к Аицу, а что - не очень, что хорошо и УАобно носить зимой, что - летом, что - в межсе- 
зонье. Кроме того, какую обувь и аксессуары подобрать к одежде.

Что касается идеи создания Банка развития БРИКС, то, на основании провеАённого исследования, важно сАелать слеАующие закАючения:

1) Аля создания Банка развития БРИКС ресурсной базы стран-организаторов вполне Аостаточно;

2) Важно отметить территориальный разрез Аействия Банка: страны БРИКС облаАают колоссацьной Аолей территории земного шара. Вместе с тем, кажАая из стран БРИКС явмяется центром притяжения стран-союзников как в своём географическом регионе, так и за его пределами. Например, союзниками РФ явцяются как Беморуссия и Казахстан, имеющие общие границы, так и Боливия, Венесуэла, Южная Корея, не имеющие общих границ с РФ.

Создание Банка развития БРИКС способно привести к слеАующим важным резумьтатам:

а) Коблегчению и упрощению внешнеэкономических операций и платежей как межАу странами БРИКС, так и странами- партнёрами указанного союза;

6) К укреплению и совершенствованию платёжной системы кажАой из стран БРИКС;

в) К укреплению национацьных валют стран- участниц БРИКС;

г) К укреплению национацьных экономик стран-участниц БРИКС, их Аиверсификации и интенсификации;
А) Возможности преобразования потенциала финансовых и экономических ресурсов стран БРИКС в инструмент внешнеполитического вАияния;

е) Возможности стран-участниц БРИКС, их партнёров и союзников самостоятельного решения собственных внутриэкономических и внутриполитических проблем. При этом сохранять открытость, прозрачность, постоянно сохран ять готовность к конструктивному взаимодействию с финансовыми организациями и странами по всему миру.

P.S. Шестого августа 2014 г. со стороны России были введены торговые санкции против стран Евросоюза, КанаАы, Австралии, суть которых состоит в запрете ввоза продуктов питания из этих стран. Страны Евросоюза, Аця которых экспорт указанных продуктов в Россию явцяется существенной статьёй Аоходов, заявили о политизированности упомянутых санкций. Появились информационные сообщения, в которых российскую сторонупризывают решать экономические вопросы рыночными методами, а не политическими. То, что политические методы используются Аля экономического Аавления, в частности, на российские банки, Аействующие за преАелами России, рассматривается только российской стороной. Более того, ни оАин российский банк, из Аействующих за рубежом (речь иАёт о таких гигантах мирового банковского Аела, как ВЭБ, ВТБ, Промсвязьбанк и Ар.) не нарушим Аействующего законодательства тех стран, на территории которых они осуществляют своюдеятельность.

\section{БИБАИОГРАФИЯ}

1. Всемирный Банк: [Официамьный сайт]. URL: http://www.worldbank.org/ru/about/history (05.07.2014).

2. Европейский Банк реконструкции и развития: [Официальный сайт]. URL: http://www. ebrd.com/downloads/research/guides/basicsru.pdf (05.07.2014).

3. Информационное агентство РИА Новости: [Официальный сайт]. URL: http://ria.ru/ economy/20140729/1018050570.html (17.07.14).

4. Медиа-портал РосБизнесКонсалтинг: [Официальный сайт]. URL: http://top.rbc.ru/ economics/16/07/2014/936727.shtml (17.07.14).

5. Министерство иностранных Аел Российской Фелерации: [Официальный сайт]. URL: http://www.mid.ru/BDOMP/Brp_4.nsf/arh/5E8FEB175512FF4D44257D2B00554201?Open Document (18.07.2014).

6. Кувалин А. Б. Экономическая политика и повеАение преАприятий: механизмы взаимного влияния. М.: МАКС Пресс, 2009.

7. Эмектронный Журнац Института мировой экономики и межАународных отношений: URL: 
http://www.imemo.ru/files/File/ru/publ/2009/09017.pdf. (18.07.14).

8. Центральный Банк России: [Официальный сайт]. URL: http://www.cbr.ru/publ/ MoneyAndCredit/Smyslov_01_12.pdf (18.07.14).

9. Манойло А.В. Политические конфликты в международных отношениях и мировой политике// Журнальный кмуб “Интекрос: Мир и политика”. 2013. №2.

10. Манойло А.В. Президент Обама и его Континентацьная блокаАа России// Журнал “NB: Международные отношения”. 2014. № 04. С. 1-6.

11. Эмектронный Журнал межАународного профимя Вестник MГИMO: URL: http://www. vestnik-old.mgimo.ru/index.php?option $=$ com_content\&view $=$ article\&id=469\&Itemid $=4$.

12. Яковлева Н.С. Страны БРИКС в современном мире// Журнальный кцуб “Интелрос: Мир и политика”. 2013. №2.

13. Эмектронное периодическое изАание Ведомости: [Официальный сайт]. URL: http://www. vedomosti.ru/finance/news/29609301/ssha-vveli-sankcii-protiv-treh-gosbankov (7.08.2014).

14. Петрикова Е.М. Тенденции развития платежного баманса и межАународной инвестиционной позиции стран БРИК// Финансы и креАит. № 29. 2009. С. 29-43. МежАународный валютный фонА: [Официальный сайт]. URL: http://www.imf.org/external/country/index. htm (8.07.2014).

15. Министерство финансов Российской федерации: [Официальный сайт]. URL: http://www. minfin.ru/ru/macroeconomics/index.php (8.07.2014).

16. Эмектронный Журнам Вестник МГИМО: URL: http://www.vestnik.mgimo.ru/sites/default/ files/pdf/ilyin.pdf (28.07.2014).

17. Консалтинговая компания АксионБКГ: [Сайт компании]. URL: http://www.bkg.ru/library/ articles/?ELEMENT_ID=3185 (29.07.2014).

18. Цыганков А.П. Русофобия в США// МежАународные процессы. 2006. №3. С.

19. Хрусталёв М.А. Эволюция системы международных отношений и особенности её современного этапа. М.: Космополис, 1999. 21. Шейнис В.А. Национальные интересы и внешняя политика России// Мировая экономика и межАународные отношения. 2003. № 4. С. 33-46. 22. Andrei Manoilo. "Revoluciones de los higos", elemento enfurecido o «caos controlado»? // Vida Internacional. Digest. 2011.pp. 148-162.23. Манойло А.В. Модемь информационно-психологической операции в межАународных конфмиктах. // Право и политика.-2008.-№6. С.1387-1394. 24. Манойло А.В. Управмение конфмиктами. Модемь психомогической операции. // Акмеология.-2009.-№1. - С. 64-74.

20. Гушер А.И. Политический кризис на Украине // NB: МежАународные отношения. 2014. — 3. — C. 15 - 26. DOI: 10.7256/2306-4226.2014.3.11502. URL: http://www.e-notabene. $\mathrm{ru} /$ wi/article_11502.html

21. Шугуров М.В. Многосторонние банки развития (МБР): формирование режима «перекрестного» исполнения решений о санкциях (cross-debarment regime) // МежАународное право и межАународные организации / International Law and International Organizations. 2013. - 3. - C. 309 - 322. DOI: 10.7256/2226-6305.2013.3.9048.

22. Гушер А.И. Экспертная оценка политико-экономической ситуации в Украине // МежАународные отношения. — 2014. - 3. - C. 326 - 331. DOI: 10.7256/2305-560X.2014.3.11815.

23. И.А.Холов Евразийский Союз, проблемы и перспективы развития // Право и политика. 2012. - 5. - С. 909 - 916.

24. Аолгих И.П., Черняев Г.М. О юриАической стороне национального вопроса // NB: Вопросы права и политики. — 2014. - 1. - C. 45 - 53. DOI: 10.7256/2305-9699.2014.1.10788. URL: http://www.e-notabene.ru/lr/article_10788.html

25. С. А. КонАаков Трубопроводная Аипломатия России // Международные отношения. 2012. - 1. - C. $128-138$.

26. А.Г.Алексеева Правовое регулирование мониторинга финансовой устойчивости банков в целях обеспечения банковской безопасности // Политика и Общество. - 2011. - 6. - C. 45 - 52. 


\section{REFERENCES (TRANSLITERATED)}

1. Vsemirnyi Bank: [Ofitsial'nyi sait]. URL: http://www.worldbank.org/ru/about/history (05.07.2014).

2. Evropeiskii Bank rekonstruktsii i razvitiya: [Ofitsial'nyi sait]. URL: http://www.ebrd.com/ downloads/research/guides/basicsru.pdf (05.07.2014).

3. Informatsionnoe agentstvo RIA Novosti: [Ofitsial'nyi sait]. URL: http://ria.ru/ economy/20140729/1018050570.html (17.07.14).

4. Media-portal RosBiznesKonsalting: [Ofitsial'nyi sait]. URL: http://top.rbc.ru/ economics/16/07/2014/936727.shtml (17.07.14).

5. Ministerstvo inostrannykh del Rossiiskoi Federatsii: [Ofitsial'nyi sait]. URL: http://www. mid.ru/BDOMP/Brp_4.nsf/arh/5E8FEB175512FF4D44257D2B00554201?OpenDocument (18.07.2014).

6. Kuvalin D. B. Ekonomicheskaya politika i povedenie predpriyatii: mekhanizmy vzaimnogo vliyaniya. M.: MAKS Press, 2009.

7. Elektronnyi Zhurnal Instituta mirovoi ekonomiki i mezhdunarodnykh otnoshenii: URL: http:// www.imemo.ru/files/File/ru/publ/2009/09017.pdf. (18.07.14).

8. Tsentral'nyi Bank Rossii: [Ofitsial'nyi sait]. URL: http://www.cbr.ru/publ/MoneyAndCredit/ Smyslov_01_12.pdf (18.07.14).

9. Manoilo A.V. Politicheskie konflikty v mezhdunarodnykh otnosheniyakh i mirovoi politike// Zhurnal'nyi klub “Intelros: Mir i politika”. 2013. №2.

10. Manoilo A.V. Prezident Obama i ego Kontinental'naya blokada Rossii// Zhurnal "NB: Mezhdunarodnye otnosheniya”. 2014. № 04. S. 1-6.

11. Elektronnyi Zhurnal mezhdunarodnogo profilya Vestnik MGIMO: URL: http://www.vestnikold.mgimo.ru/index.php?option=com_content\&view $=$ article\&id=469\&Itemid $=4$.

12. Yakovleva N.S. Strany BRIKS v sovremennom mire// Zhurnal'nyi klub "Intelros: Mir i politika". 2013. №2.

13. Elektronnoe periodicheskoe izdanie Vedomosti: [Ofitsial'nyi sait]. URL: http://www.vedomosti. $\mathrm{ru} /$ finance/news/29609301/ssha-vveli-sankcii-protiv-treh-gosbankov (7.08.2014).

14. Petrikova E.M. Tendentsii razvitiya platezhnogo balansa i mezhdunarodnoi investitsionnoi pozitsii stran BRIK// Finansy i kredit. № 29.2009. S. 29-43. Mezhdunarodnyi valyutnyi fond: [Ofitsial'nyi sait]. URL: http://www.imf.org/external/country/index.htm (8.07.2014).

15. Ministerstvo finansov Rossiiskoi federatsii: [Ofitsial'nyi sait]. URL: http://www.minfin.ru/ru/ macroeconomics/index.php (8.07.2014).

16. Elektronnyi Zhurnal Vestnik MGIMO: URL: http://www.vestnik.mgimo.ru/sites/default/files/ pdf/ilyin.pdf (28.07.2014).

17. Konsaltingovaya kompaniya AksionBKG: [Sait kompanii]. URL: http://www.bkg.ru/library/ articles/?ELEMENT_ID=3185 (29.07.2014).

18. Tsygankov A.P. Rusofobiya v SShA// Mezhdunarodnye protsessy. 2006. №3. S.

19. Khrustalev M.A. Evolyutsiya sistemy mezhdunarodnykh otnoshenii i osobennosti ee sovremennogo etapa. M.: Kosmopolis, 1999. 21. Sheinis V.L. Natsional'nye interesy i vneshnyaya politika Rossii// Mirovaya ekonomika i mezhdunarodnye otnosheniya. 2003. № 4. S.33-46. 22. Andrei Manoilo. "Revoluciones de los higos", elemento enfurecido o «caos controlado»? // Vida Internacional. Digest. 2011. pp. 148-162. 23. Manoilo A.V. Model' informatsionno-psikhologicheskoi operatsii v mezhdunarodnykh konfliktakh. // Pravo i politika.-2008.-№6. - S.1387-1394. 24. Manoilo A.V. Upravlenie konfliktami. Model’ psikhologicheskoi operatsii. // Akmeologiya.-2009.-№1. - S. 64-74.

20. Gusher A.I. Politicheskii krizis na Ukraine // NB: Mezhdunarodnye otnosheniya. - 2014. 3. - C. 15 - 26. DOI: 10.7256/2306-4226.2014.3.11502. URL: http://www.e-notabene.ru/ wi/article $11502 . \mathrm{html}$

21. Shugurov M.V.Mnogostoronnie banki razvitiya (MBR): formirovanie rezhima «perekrestnogo» ispolneniya reshenii o sanktsiyakh (cross-debarment regime) // Mezhdunarodnoe pravo i 
mezhdunarodnye organizatsii / International Law and International Organizations. — 2013. 3. - C. 309 - 322. DOI: 10.7256/2226-6305.2013.3.9048.

22. Gusher A.I. Ekspertnaya otsenka politiko-ekonomicheskoi situatsii v Ukraine // Mezhdunarodnye otnosheniya. - 2014. - 3. - C. 326 - 331. DOI: 10.7256/2305-560X.2014.3.11815.

23. I. A. Kholov Evraziiskii Soyuz, problemy i perspektivy razvitiya // Pravo i politika. — 2012. 5. - C. $909-916$.

24. Dolgikh I.P., Chernyaev G.M. O yuridicheskoi storone natsional'nogo voprosa // NB: Voprosy prava i politiki. - 2014. - 1. - C. 45 - 53. DOI: 10.7256/2305-9699.2014.1.10788. URL: http://www.e-notabene.ru/lr/article_10788.html

25. S. A. Kondakov Truboprovodnaya diplomatiya Rossii // Mezhdunarodnye otnosheniya. 2012. - 1. - C. $128-138$.

26. D. G. Alekseeva Pravovoe regulirovanie monitoringa finansovoi ustoichivosti bankov v tselyakh obespecheniya bankovskoi bezopasnosti // Politika i Obshchestvo. — 2011. - 6. - C. 45 - 52 . 